\title{
Uluslararasılaşma Düzeyi Üzerinde Farklı Kaynak Unsurlarının Kısa ve Uzun Dönem Etkisi \\ (The Short- and Long-Term Effect of Different Capital Structure on Internationalization)
}

\section{İlkut Elif KANDİL GÖKER iD a}

aKırıkkale Üniversitesi, İktisadi ve İdari Bilimler Fakültesi İşletme Bölümü, Muhasebe ve Finansman Anabilim Dalı. elifkandil@kku.edu.tr

\begin{tabular}{|c|c|}
\hline MAKALE BİLGİSİ & ÖZET \\
\hline Anahtar Kelimeler: & $\begin{array}{l}\text { Amaç - Bu çalışmanın amacı firmaların sermaye yapılarını oluşturan farklı kaynak unsurlarının } \\
\text { ihracat performansları üzerindeki etkisinin kısa ve uzun dönemde araştırılmasıdır. }\end{array}$ \\
\hline Sermaye Yapısı & $\begin{array}{l}\text { Yöntem - BIST'e kote olmuş Dokuma Giyim Eşyası ve Deri Sektörü firmalarının 2008-2018 dönemi } \\
\text { yıllık finansal tablolarını toplulaştırılması ile elde edilen toplulaştırılmış bilanço verileri } \\
\text { kullanılarak kısa ve uzun dönemli ilişki ARDL ve Hata Düzeltme Modeli ile incelenmiştir. }\end{array}$ \\
\hline $\begin{array}{l}\text { Gönderilme Tarihi } 21 \text { Ekim } \\
2019 \\
\text { Revizyon Tarihi } 20 \text { Aralık } 2019 \\
\text { Kabul Tarihi } 26 \text { Aralık } 2019\end{array}$ & $\begin{array}{l}\text { Bulgular - Kısa vadeli yabancı kaynak oranı, uzun vadeli yabancı kaynak oranı ve özkaynak oranı } \\
\text { olarak ifade edilen farklı kaynak unsurlarının işletmelerin uluslararasılaşma düzeyleri üzerinde kısa } \\
\text { dönemde anlamlı bir etkisi olmadığı ancak bununla beraber kısa ve uzun vadeli yabancı kaynağın } \\
\text { toplam kaynak içindeki payının artmasının işletmelerin uluslararasılaşmasını negatif yönde } \\
\text { etkilerken özsermayenin toplam kaynak içindeki payının artmasının pozitif yönde etkilediği tespit } \\
\text { edilmiştir. }\end{array}$ \\
\hline
\end{tabular}

Tartışma - Uzun dönemde, işletmelerin kısa vadeli borçlanma oranı ve uzun vadeli borçlanma oranı ile uluslararasılaşma düzeyleri arasında negatif yönlü bir ilişki; özkaynak oranı ile pozitif yönlü bir ilişki söz konusudur. Dokuma Giyim Eşyası ve Deri Sektörü şirketleri için gerek kısa vadeli, gerek uzun vadeli borçlanma oranında yaşanan artış, sözü edilen şirketlere finansal yükümlülükler yüklemekte ve bu durumda yöneticiler için beklenen nakit akışlarını ve uluslararasılaşma ihtimallerini azaltııı bir etki yaratmaktadır. Buna karşılık özsermayenin toplam kaynak içindeki payının artması uluslararasılaşmayı pozitif yönde etkilemektedir. Bu nedenle ele alınan sektörün uluslararasılaşma planlarını özsermaye finansmanına dayalı olarak planlamaları gerekmektedir.

\section{Makale Kategorisi: \\ Araştırma Makalesi}

\section{ABSTRACT}

Purpose - The aim of this study is to investigate the effect of different source elements which constitute the capital structure of firms on export performance in short and long term.

Design/methodology/approach - The aggregated balance sheet data obtained by aggregating the financial statements of the Weaving, Apparel and Leather Sector companies listed on the BIST were used. The short and long term relationship was estimated with ARDL and Error Correction Model.

Findings - While the different source elements, which are expressed as short-term liabilities, longterm liabilities and equity ratios, do not have a significant effect on the internationalization levels of enterprises in the short term, however, the increase in the share of short-term and long-term liabilities in total resources negatively affects the internationalization of enterprises in long term. It was determined that the increase of the share of equity in the total resource had a positive effect on internationalization of enterprises in long term.

Discussion - In the long term, there is a negative relationship between the short-term borrowing rate and long-term borrowing rate and internationalization levels of enterprises; There is a positive relationship with equity ratio. The increase in both short-term and long-term borrowing rates for Woven Weaving, Apparel and Leather Sector companies imposes financial obligations on these companies and in this case decreases the expected cash flows and internationalization possibilities for managers.On the other hand, the increase in the share of equity in the total resource affects the internationalization positively.Therefore, the sector in question needs to plan its internationalization plans based on equity financing.

\section{Önerilen Atıf/Suggested Citation}

Kandil Göker., İ. E. (2019) Uluslararasılaşma Düzeyi Üzerinde Farklı Kaynak Unsurlarının Kısa ve Uzun Dönem Etkisi, İşletme Araştırmaları Dergisi, 11 (4), 3448-3457. 


\section{GİRIŞ}

Klasik ticaret teorisi, işletmelerin düşük maliyetli hammadde ve ucuz işgücüne doğrudan erişim ihtiyacı doğrultusunda çokuluslu işletme olma amacı taşıdığını öne sürmektedir (Shapiro, 1992). Bununla birlikte işletmelerin sahip oldukları patent, know-how, genel yönetim yetenekleri ve pazarlama kabiliyetleri gibi maddi olmayan varlıkların maliyeti tamamen ürün fiyatlarına yansıtılamadığı için işletmeler söz konusu varlıklarını korumak ve kontrol edebilmek için faaliyetlerine uluslararası düzeye taşımayı istemektedirler. Jensen (1986) ise işletmeleri uluslararasılaşmaya yönelten sebepleri serbest nakit akışları hipotezi ile açıklamıştır. Bu hipotez, serbest nakit akışına sahip olan ve yurtiçinde yatırım fırsatı bulamayan yöneticilerin uluslararası projelere yatırım yapma arayışında olacağını savunmaktadır. Yöneticiler, negatif bir nakit akışı öngörse bile yurtdışı yatırımdan, yükselecek statüleri ve alacakları ek gelir nedeniyle vazgeçmeyeceklerdir.

Finans teorisi, çokuluslu işletmelerin ulusal düzeyde faaliyet gösteren işletmelere göre daha yüksek bir borçlanma düzeyine sahip olduğunu, bunun altında yatan sebebin çokuluslu işletmelerin göreceli olarak daha büyük ölçekte olması, nakit akış volatilitesinin daha düşük olması ve uluslararası sermaye piyasalarına artan erişim olanaklarından kaynaklandığını belirtmektedir. Ancak bununla birlikte çokuluslu işletmelerin daha düşük borçlanma düzeyine sahip olduğunu ampirik bulgulara dayanarak öne süren pek çok çalışma da mevcuttur. Bu anlamda borçlanma düzeyi ile uluslararasılaşma arasındaki ilişkinin yönü hakkında genel kabul görmüş bir kanaat mevcut değildir (Mittio \& Zhang, 2008: 706).

İşletmelerin borçlanma durumlarının en temel belirleyicileri arasında, borç/özsermaye oranı üzerinde negatif etkisi olan borcun temsil maliyeti ve borcun iflas maliyeti sayılmaktadır. Literatürde de pek çok çalışmada çokuluslu işletmeler ile ulusal düzeyde faaliyet gösteren işletmeler arasındaki borçlanma oranı farklılığı, uluslararasılaşmanın bu iki maliyet üzerindeki etkisine dayalı olarak incelenmiştir. Shapiro (1978), çokuluslu işletmelerin ulusal işletmelere göre daha düşük bir borçlanma oranına sahip olduğunu ifade etmiştir. Ülkeler arasındaki kurumsal, yasal ve sosyo-kültürel farklardan ötürü çok uluslu işletmeler daha yüksek düzeyde bilgi asimetrisine maruz kalmaktadır. Söz konusu bilgi asimetrisi ise toplam sermaye maliyetini artırmaktadır (Burgman,1996). Bununla birlikte uluslararası faaliyetlerde her şeyin çok açlk bir şekilde görülememesi nedeniyle ekstra gözlem maliyetleri ortaya çıkmaktadır. Artan gözlem maliyetleri borç verenler ile hissedarlar arasında yönetici ve hissedarlar arasında olan vekalet problemine benzer şekilde bir çıkar çatışması oluşturmaktadır (Singh ve Nejadmalayeri, 2004). Çokuluslu işletmelerin sahip oldukları tekelci güç nedeniyle kendi ülkelerindeki yerel işletmelerden daha iyi performans gösterdikleri ve bu durumun da işletmelerin gelecekteki büyüme değerine yansiyarak söz konusu işletmeler için borcun temsil maliyetinin daha yüksek olması ve işletmelerin borç oranlarının düşmesi ile sonuçlandığı da ifade edilmektedir (Chen, Cheng vd., 1997). Diğer taraftan çeşitlendirmenin sağlamış olduğu fayda sayesinde daha fazla uluslararası faaliyetlerde bulunan işletmelerin riski, işletmeye borç verenler açısından düşecek, eş zamanlı olarak uluslararası faaliyetlere özgü risklere bağlı olarak (döviz kuru riski) özsermayenin riskliliği artacaktır. Özellikle çokuluslu işletmelerin toplam sermaye maliyetinin bir bileşeni olarak borcun maliyetini azaltmak için daha yüksek oranda borçla finansmanı tercih etmeleri söz konusu olabilmektedir. Bu durumda daha yüksek finansal kaldıraçtan yararlanmış olma durumu özsermaye maliyeti artışına sebep olacaktır (Reeb vd. 2001). Burgman (1996)'ın, çokuluslu işletmelerin ulusal işletmelere göre borcun temsil maliyeti sorunundan ötürü sermaye yapılarında daha az borca yer verdikleri görüşünün aksine, Mansi ve Reeb (2002), borçlanmanın maliyetinin çokuluslu işletmelerde ulusal işletmelere göre daha düşük olmasından dolayı sermaye yapılarında daha fazla borca yer verdiklerini öne sürmüştür. Bu bağlamda, bu çalışma ile literatürde bulgular anlamında farklılaşan uluslararasılaşma ile firmaların kaynak unsurları arasındaki ilişkinin araştırılması amaçlanmaktadır.

\section{Literatür İncelemesi}

Uluslararası ticaret ve finans teorileri, firmaların uluslararasılaşması ve bu uluslararasılaşmanın sermaye yapısı ve sermaye maliyeti üzerindeki etkisini ya da tam tersi olarak sermaye yapısı ve sermaye maliyetinin uluslararasılaşma üzerindeki etkisini açılamaya yönelik geliştirilen pek çok hipotezin bulgularını içermektedir. Ele alınan çalışmaların büyük bölümünde işletmelerin sermaye yapıları finansal kaldıraç oranı ile ifade edilmekte; uluslararasılaşma düzeyi ise toplam satışlarının içindeki yurtdışı satışların payı ve toplam varlıklarının içindeki yurtdışı varlıklarının payı ile ifade edilmektedir. Bununla birlikte çalışmalarda borçlanma düzeyi borcun vadesine göre düzenlenerek kısa vadeli borçlanma oranı ve uzun vadeli borçlanma oranı şeklinde de ele alınmaktadır. Uluslararasılaşma ve borçlanma düzeyi ilişkisini araştırmaya yönelik 
çalışmalar Shapiro (1978) ile başlamış olup günümüzde de hali hazırda pek çok çalışmanın araştırma sorusunu teşkil etmektedir.

Chen vd. (1997), 1984-1993 dönemi için 10 milyon doların üzerinde toplam varlığa sahip 18.495 işletmenin verilerini kullanarak işletmelerin borç yapısı ile uluslararasılaşması arasındaki ilişki incelemişlerdir. Daha önce yapılan çalışmalarda sermaye yapısına ilişkin vekalet teorisine uyumlu olarak daha düşük borçlanma düzeyi ile çokuluslu işletme olma arasındaki pozitif ilişkinin ve çokuluslu işletmelerin daha fazla büyüme avantajına sahip olması durumunun, ele aldıkları çalışmada elde edilen bulgular ile uyumlu olduğunu belirtmişlerdir. Aynı büyüklükte, aynı iflas maliyetine sahip, aynı büyüme olanakları olan ve karlılıkları aynı olan iki işletmeden çokuluslu olan işletmenin toplam borç oranının ulusal işletmeye göre daha düşük olacağını öne sürmüşlerdir.

Chkir ve Cosset (2001), 1992-1996 dönemi kesintisiz verilerine ulaşılabilen Standart\& Poor's Compustat veri tabanında yer alan ve bilançosunda yabancı vergi beyan eden 973 firma örnekleminde çokuluslu işletmelerin sermaye yapıları ile çeşitlendirme stratejileri arasındaki ilişkiyi incelmişlerdir. Elde ettikleri bulgulara göre finansal kaldıraçtan yaralanmış olma düzeyinin firmaların uluslararası çeşitlendirmelerini arttırdığını öne sürmüşlerdir. Bununla birlikte her ne kadar çokuluslu işletmelerin sermaye yapısının belirleyicilerinin rolü çeşitlendirme stratejisine göre değişiklik gösterse de; ortak belirleyicilerin varlı̆̆ının söz konusu olduğunu, iflas ve karlılık risklerinin çokuluslu işletmelerin borçlanma oranları ile negatif ilişkili olduğunu tespit etmişlerdir.

Singh ve Nejadmalayeri (2004), Stern Stewart veritabanında yer alan 1999 yılında en iyi performansa sahip 190 Fransız firmasının 1996-1999 dönemi verilerini kullanmak suretiyle uluslararası çeşitlendirme, sermaye yapısı ve sermaye maliyeti arasındaki ilişkiyi incelemişlerdir. Uluslararası çeşitlendirme düzeyi ile firmaların daha yüksek toplam borç oranı ve uzun vadeli borç oranı arasında pozitif bir ilişki olduğunu, uluslararası çeşitlendirme düzeyi ve kısa vadeli borçlanma düzeyi arasında ise ters yönlü U şeklinde doğrusal olmayan bir ilişkinin söz konusu olduğunu tespit etmişlerdir. Uluslararasılaşmış firmaların daha yüksek oranda borçla finansmana yöneldiklerini;böylece daha yüksek sermaye maliyetine karşı toplam sermaye maliyetini düşürebildiklerini öne sürmüşlerdir.

Greenaway vd. (2007), 1992-2003 dönemi 9.292 İngiltere imalat firması ile oluşturdukları panel veriyi kullanarak firmaların finansal refah durumları ile ihracat pazarında yer alma kararları arasındaki ilişkiyi incelemişlerdir. İhracatçıların ihracatçı olmayanlara göre daha iyi bir finansal refah gösterdiklerini, bu ilişkinin ihracata yeni başlayanlar ile hali hazırda ihracatçı olup ihracat yapmayı sürdüren firmalar özelinde incelenmesi neticesinde ihracata yeni başlayanların düşük likidite ve yüksek finansal kaldıraca sahip olduklarını belirtmişlerdir. İhracata yeni başlayanların yüksek finansal kaldıraca sahip olmalarını ise ihracat yapılacak pazara girmenin beraberinde getirdiği sabit maliyetlere bağlamışlardır. Daha önceden finansal yapısı güçlü olan firmaların ihracata başlamaya daha istekli oldukları görüşünü destekler bulgular elde etmediklerini ifade etmişlerdir.

Chiang ve Chen (2008), 2001-2005 döneminde Tayvan Menkul Kıymetler Borsa'sında işlem görmekte olan ve finansal olmayan firmalardan bir örneklem oluşturarak uluslararasılaşma ile sermaye yapısı arasındaki ilişkiyi incelemiştir. İşletmeleri, yurtdışı satış ve yurtdışı varlık oranlarına göre yurtiçinde faaliyet gösteren işletme ve çokuluslu işletme olarak sınıflandırmışlardır. Elde ettikleri bulgulara göre çokuluslu işletmelerin yurtiçinde faaliyet gösteren işletmelere göre daha az finansal kaldıraç oranına sahip olduklarını, ayrıca daha düşük işletme riski, daha düşük döviz kuru riski ve daha yüksek temsil maliyetine sahip olduklarını ifade etmişlerdir. Ancak uluslararasılaşma düzeyi ile finansal kaldıraç arasındaki ilişkinin bir eşik noktası olduğunu; bu eşik noktasına kadar ilişkinin yönünün negatif olduğunu, sonrasında ilişki yönünün pozitife döndüğünü belirtmişlerdir.

Bellone, Musso ve diğerleri (2010) firmaların karşılaşacakları ticari engellerin firmalar için önden ödenmiş sabit maliyet unsuru olduğunu ifade etmişlerdir. Bu sabit maliyet unsurların içeren bazı harcamalarihracat yapılacak ülkeye yönelik firmaların yapacakları ölü yatırım olabilme ihtimali karşısında söz konusu firmaların ihracat performanslarını sürdürecekleri yeterli fon kaynağı bulmakta zorlanabileceklerini belirtmiş; bu sebepten ötürü ihracatı ancak finansal kaynak temini ve yönetiminde sıkıntı yaşamayan firmaların yapabileceğini vurgulamıştır. Diğer yandan ihracat yapıyor olmanın dişsal finansal kaynaklara erişimini kolaylaştırdığını ifade etmişlerdir. İhracat yapan firmaların, satışlarının uluslararası boyuta taşınması 
sayesinde istikrarlı bir nakit akışı sağladıklarını, talep yönlü şoklardan zarar görme olasılıklarının düştüğünü, uluslararası piyasalarda faaliyet gösteriyor olma imajının iç pazarda olumlu etki yarattığını vurgulamışlardır. Çalışmalarında 1993-2005 döneminde Fransa'da faaliyet gösteren 25.000 imalat firması verilerini kullanarak yaptıkları analiz sonucunda ülke dışında faaliyete başlamadan önce ihracatçı olacak firmaların ihracatçı olmayan firmalara göre finansman yapısının daha güçlü olduğunu, dışsal kaynaklara erişim gücünün ihracatı önemli bir belirleyicisi olduğunu belirtmişlerdir. Buna karşılık uluslararasılaşmanın finansal piyasalara daha kolay erişim sağladığı hipotezini destekler sınırlı bulgularının olduğunu; esasında oldukça yoğun düzeyde ihracat yapan firmaların yabancı piyasalara girişini takip eden yıllarda daha iyi bir finansal refaha ulaştıklarını, ancak bunun da çok sağlam bulgularla ortaya konulmadığını öne sürmüşlerdir.

Minetti ve Zhu (2011), İtalya' da 10 kişiden fazla çalışanı olan 4.680 imalat firmasına uygulanan anket verilerini kullanarak kredi sınırlandırmasının firmaların ihracata bakış açıları ve yurtdışı satışları üzerindeki etkisini incelemişlerdir. Firmaları, farklı kaynak unsurlarına yönelten kredi sınırlandırması aynı nitelikleri taşıyan ve dışsal kaynaklardan fon temin etmek isteyen potansiyel kredi kullanıcılarından bazılarının kredi kullanabilirken bazılarının ise daha yüksek bir faiz oranı ile borçlanmayı kabul etseler bile borçlanamadıkları durum olarak izah edilmektedir. Elde ettikleri bulgulara göre kredi sınırlandırmasına maruz kalan firmaların ihracat yapma ihtimalleri diğer gruba göre \%39 daha düşük gerçekleşmekte; bir başka ifade ile kredi sınırlandırması, yurtdışına satışları \%38'den fazla oranda düşürmektedir. Kredi sınırlandırmalarının yurtdışına satışlara olan negatif etkisi, yurtiçi pazara yönelik kredi sınırlandırmalarına göre anlamlı olarak daha yüksektir. Kredi sınırlandırmasının özellikle dışsal finans kaynaklarına bağımlılığı daha yüksek olan firmaların ihracatlarını azalttığı ifade etmişlerdir.

Pacheco (2017), Portekiz'de faaliyet göstermekte olan 3.164 küçük ve orta büyüklükte firma (KOBİ) örneklemine ait 2011-2014 dönemi verilerini kullanmak suretiyle firmaların finansman yapıları ile uluslararasılaşmaları arasındaki ilişkiyi incelemiştir. Özellikle temsil sorunu ve kaynak yoksunluğunun ihracat performansı üzerinde daha fazla etki edeceği beklentisinden dolayı KOBİ örnekleminin seçildiği belirtilmiştir. Elde edilen bulgulara göre daha az borç, daha yüksek karlılığa sahip ve ölçek olarak daha büyük firmaların daha fazla ihracat yoğunluğu ve ihracat çeşitlendirmesine sahip oldukları ifade edilmiştir. Uygulanan Tobit modelde finansman yapısı toplam borcun, kisa vadeli borcun ve uzun vadeli borcun toplam aktife oranlanması ile elde edilen üç farklı değişken ile temsil edilmiştir. Kısa vadeli borçlanma oranının ihracat yoğunluğu ve çeşitliliğini pozitif yönde etkilediği; toplam borçlanma oranı ve uzun vadeli borçlanma oranının ise negatif yönde etkilediği tespit edilmiştir. Bu durumun uluslararasılaşmak isteyen firmaların kısa vadeli borçlanmaya başvurması gerektiğinin bir göstergesi olduğunu belirtmiştir.

Lee ve Khaw (2019), Malezya'da borsaya kote, finansal olmayan 517 firma verisini kullanarak 2000-2014 dönemi için uzun vadeli borç ve uluslararasılaşma arasındaki ilişkiyi temsil maliyeti ve işletme riski varlığı altında incelemiştir. Elde ettikleri bulgulara göre çok uluslu işletmelerin temsil maliyeti ve firma riski ile ilişkili maliyetleri azaltmak amacıyla ulusal işletmelere göre daha düşük bir uzun vadeli borçlanma düzeyini sürdürdükleri, aynı zamanda yabancı kaynaklı çok uluslu işletmelerin ulusal işletmelere göre daha düşük bir borçlanma düzeyini sürdüklerini, uzun vadeli borçlanma ile uluslararasılaşma arasında negatif bir ilişki tespit ettiklerini belirtmişlerdir.

Uluslararasılaşma ile firmaların borçlanma düzeyleri arasındaki ilişkiyi inceleyen çalışmaların bir kısmı çokuluslu işletme statüsünde olan işletmelerin daha yüksek bir borçlanma düzeyine sahip olduklarını; diğer kesim ise daha düşük bir borçlanma düzeyine sahip olduklarını belirtmektedir.

\section{Metodoloji}

\subsection{Araştırma Metodu}

Bu çalışmada uluslararasılaşma düzeyi ile farklı kaynak unsurları arasındaki ilişkinin incelenmesi amacıyla ARDL sınır testi yaklaşımı kullanılmıştır. ARDL sınır testi yaklaşımı, değişkenler arasında uzun dönemli bir eşbütünleşmenin var olup olmadığını test etmek üzere geliştirilmiş bir model olup tipik bir ARDL modeli aşağıdaki şekilde ifade edilmektedir (Pesaran vd., 2001).

$$
\Delta L n Y_{t}=c+\sum_{i=1}^{k_{1}} \alpha_{1} \Delta L n Y_{t-1}+\sum_{i=1}^{k_{2}} \alpha_{2} \Delta L n X_{t-1}+\sum_{i=1}^{k_{3}} \alpha_{3} \Delta L n Z_{t-1}+\alpha_{4} L n Y_{t-1}+\alpha_{5} \operatorname{LnX} X_{t-1}+\alpha_{6} L n Z_{t-1}+\mu_{t}
$$


Modelde c sürükleme terimi, $\Delta$ birinci fark çalıştırıcı, $\mu$ beyaz gürültülü hata terimi olarak adlandırılmaktadır. Tüm seriler doğal logaritmik formundadır. Bound Test uzun dönemli ilişkinin varlığını sınamak üzere kullanılan F-Test'e dayanmaktadır. F-Test bir boş hipotez testidir. Ho aşağıdaki gibi gösterilmektedir.

$\mathrm{H}_{0}: \alpha_{4}=\alpha_{5}=\alpha_{6}=0$

Halt: $\alpha_{4} \neq \alpha_{5} \neq \alpha_{6} \neq 0$

Eğer $\mathrm{H}_{0}$ reddedilirse değişkenler arasında bir eşbütünleşme olduğu kabul edilir. Eğer ele alınan değişkenler arasında bir eşbütünleşme tespit edilirse söz konusu değişkenler arasındaki uzun ve kısa dönemli ilişkinin ARDL modeli ile tespit edilmesi de mümkündür. Üçüncü olarak da ARDL modeli ve ECM modeli ile değişkenlerin uzun ve kısa dönemli katsayılarının hesaplanabilmektedir. Uzun dönem ARDL modeli aşağıdaki şekilde ifade edilmektedir:

$$
\Delta L n Y_{t}=c+\sum_{i=1}^{k_{1}} \alpha_{1} \Delta L n Y_{t-1}+\sum_{i=1}^{k_{2}} \alpha_{2} \Delta L n X_{t-1}+\sum_{i=1}^{k_{3}} \alpha_{3} \Delta L n Z_{t-1}+\mu_{t}
$$

Yukarıdaki modelde $\alpha_{1}, \alpha_{2}$ ve $\alpha_{3}$ ARDL modelinin uzun vadeli katsayılarını belirtmektedir. Hata düzeltme modeli ile kısa vadeli katsayılar ise aşağıdaki gibi hesaplanmaktadır.

$$
\Delta L n Y_{t}=c+\sum_{i=1}^{k_{1}} \alpha_{1} \Delta L n Y_{t-1}+\sum_{i=1}^{k_{2}} \alpha_{2} \Delta L n X_{t-1}+\sum_{i=1}^{k_{3}} \alpha_{3} \Delta L n Z_{t-1}+\alpha_{4} E C M_{t-i}+\mu_{t}
$$

Yukarıdaki modelde $\alpha_{1}, \alpha_{2}$ ve $\alpha_{3}$ ARDL modelinin kısa vadeli katsayılarını, ECM hata düzeltme terimini ve $\alpha_{4}$ düzeltme hızı parametresini belirtmektedir.

\subsection{Veri Seti}

Çalışmada, BIST'te işlem gören Dokuma Giyim Eşyası ve Deri Sektörü şirketlerine ait veriler ele alınmıştır. Söz konusu veriler Kamu Aydınlatma Platformu web sayfasından temin edilmiştir. 2008-2018 dönemi çeyrek dönem bilanço verileri kullanılmıştır. Sektörde, hisse senetleri borsada işlem gören toplam 22 şirket bulunmaktadır. Bu şirketlerden 9 tanesinin çalışmada ele alınan dönem itibariyle eksik verisi olduğu için 13 şirketin bilanço verileri kullanılmıştır. 13 şirketin bilanço kalemleri toplanarak sektöre ait toplulaştırılmış bir bilanço oluşturularak bir zaman serisi elde edilmiştir.

Sektörün uluslararasılaşma göstergesi olarak literatürde pek çok çalışmada yer alan Yurtdışı Satışların Toplam Satışlara Oranı kullanılmıştır (Borda vd., 2007, Vithessonthi ve Racela, 2016, Olmos vd. 2016, Altaf ve Shah, 2015, Xiao vd., 2013).Firmaların kaynak yapısını oluşturan üç temel unsur olarak ele alınan kısa vadeli yabancı kaynak oranı, uzun vadeli yabancı kaynak oranı ve özkaynak oranı aralarında yüksek korelasyon gösterdikleri için uluslararasılaşma düzeyinin bağımlı değişken olduğu farklı modeller kurulmuştur. Her model farklı bir kaynak yapısı unsurunu içermektedir.Modellerde kullanılan değişkenler ve hesaplanma yöntemleri Tablo 1'de gösterildiği gibidir:

Tablo 1.Modellerde Kullanılan Değişkenler

\begin{tabular}{ll}
\hline Serinin Adı & Serinin Açıllaması \\
\hline YDS & Yurtdışı Satışlar/Toplam Satışlar \\
KVYKO & Kısa Vadeli Yabancı Kaynak/ Toplam Kaynak \\
UVYKO & Uzun Vadeli Yabancı Kaynak/ Toplam Kaynak \\
OZKO & Özkaynak/Toplam Kaynak \\
\hline
\end{tabular}

Her bir kaynak unsuru oranı ile uluslararasılaşma arasındaki uzun ve kısa dönemli ilişki incelenmek istendiği için altı ayrı model kurulmuştur. Bu modellerden Model (1), (2) ve (3) uzun dönemli ilişkinin sınanması, Model (4), (5) ve (6) ise kısa dönemli ilişkinin sınanması için oluşturulmuştur. ARDL yaklaşımına dayalı Vektör hata düzeltme modelleri kısa dönemli ilişkinin açıklanmasında kullanılmaktadır. Modeller aşağıdaki şekildedir: 


$$
\begin{aligned}
& \Delta Y D S_{t}=c+\sum_{i=1}^{k_{1}} \alpha_{1} \Delta Y D S_{t-1}+\sum_{i=1}^{k_{2}} \alpha_{2} \Delta K V Y K O_{t-1}+\alpha_{3} Y D S_{t-1}+\alpha_{4} K V Y K O_{t-1}+\mu_{t}(1) \\
& \Delta Y D S_{t}=c+\sum_{i=1}^{k_{1}} \alpha_{1} \Delta Y D S_{t-1}+\sum_{i=1}^{k_{2}} \alpha_{2} \Delta U V Y K O_{t-1}+\alpha_{3} Y D S_{t-1}+\alpha_{4} U V Y K O_{t-1}+\mu_{t}(2) \\
& \Delta Y D S_{t}=c+\sum_{i=1}^{k_{1}} \alpha_{1} \Delta Y D S_{t-1}+\sum_{i=1}^{k_{2}} \alpha_{2} \Delta O Z K O_{t-1}+\alpha_{3} Y D S_{t-1}+\alpha_{4} O Z K O_{t-1}+\mu_{t} \\
& \Delta Y D S_{t}=c+\sum_{i=1}^{k_{1}} \alpha_{1} \Delta Y D S_{t-1}+\sum_{i=1}^{k_{2}} \alpha_{2} \Delta K V Y K O_{t-1}+\alpha_{3} E C M_{t-i}+\mu_{t}(4) \\
& \Delta Y D S_{t}=c+\sum_{i=1}^{k_{1}} \alpha_{1} \Delta Y D S_{t-1}+\sum_{i=1}^{k_{2}} \alpha_{2} \Delta U V Y K O_{t-1}+\alpha_{3} E C M_{t-i}+\mu_{t}(5) \\
& \Delta Y D S_{t}=c+\sum_{i=1}^{k_{1}} \alpha_{1} \Delta Y D S_{t-1}+\sum_{i=1}^{k_{2}} \alpha_{2} \Delta O Z K O_{t-1}+\alpha_{3} E{ } M_{t-i}+\mu_{t}(6)
\end{aligned}
$$

\subsection{Bulgular}

\subsubsection{Birim Kök Test Sonuçları}

Zaman serisi ekonometrik modellerinin uygulanabilmesi için ilk aşama, kullanılacak tüm serilerin durağanlığının test edilmesidir. Bu nedenle ADF ve PP testleri ile dört değişkene ait serilerin durağanlığ1 sınanmıştır. Test sonuçları Tablo 2'de gösterildiği gibidir. Uygulanan ADF ve PP birim kök testlerinin temel hipotezi, seride birim kökün var olduğunu göstermektedir. Testler sabit ve sabit- trendli olarak yapılmıştır. KVYKO, UVYKO ve ÖZKO serileri için hesaplanan test istatistikleri \%5 anlamlılık düzeyinde temel hipotez reddedilememektedir. Dolayısıyla söz konusu değişkenlerin birinci farkları alınarak testler yenilenmiştir. Son durumda elde edilen bulgulara göre \%1 anlamlllık düzeyinde YDS serisinin seviyede durağan olduğu, KVYKO, UVYKO ve ÖZKO serilerinin ise birinci farkta durağan olduğu tespit edilmiştir. Bu durumda aralarında uzun dönemli ilişkinin sınanacağı değişkenlere ait serilerin $\mathrm{I}(0)$ ve $\mathrm{I}(1)$ şeklinde olduğu görülmüştür. Bu nedenle değişkenlerin I(0) veya I(1) olduğuna bakılmaksızın uygulanabilen (Pesaran vd., 2001:290), gözlem sayısının az olması durumunda Engle-Granger ve Johansen eşbütünleşme testlerine göre daha güvenilir sonuçlar veren (Narayan ve Smyth, 2005:103) ARDL sınır testi yaklaşımının kullanılmasına karar verilmiştir.

Tablo 2. Birim Kök Test Sonuçları

\begin{tabular}{|lllll|}
\hline & ADF & & PP \\
Değişkenler & Sabit & Sabit ve Trendli & Sabit & Sabit ve Trendli \\
\hline Seviyede & & & & \\
\hline YDSO & $-6.006793^{* * * *}$ & $-6.499565^{* * * *}$ & $-6.006793^{* * * *}$ & $-6.515293^{* * * *}$ \\
KVYKO & $-1.395425^{*}$ & $-3.814650^{* * *}$ & -0.937035 & $-3.814650^{* *}$ \\
UVYKO & -0.140520 & -1.946162 & -0.165011 & -2.084300 \\
OZKO & 0.808414 & -2.525385 & 1.291561 & -2.366733 \\
Birinci Fark & & & & \\
\hline KVYKO & $-8.666040^{* * * *}$ & $-8.580891^{* * * *}$ & $-17.95254^{* * *}$ & $-18.99550^{* * * *}$ \\
UVYKO & $-4.305207^{* * * *}$ & $-4.539107^{* * * *}$ & $-4.068021^{* * * *}$ & $-4.163290^{* * * *}$ \\
OZKO & $-7.355907^{* * * *}$ & $-7.843414^{* * *}$ & $-7.359600^{* * *}$ & $-7.847990^{* * *}$ \\
\hline
\end{tabular}

***, ${ }^{* * *}$ sirasıly $\% 1, \% 5$ ve \%10 anlamlılık düzeyini ifade etmektedir.

\subsubsection{Bound Test Sonuçları}

Değişkenler arasında eşbütünleşmenin var olup olmadığını test etmek amacıyla Bound Test kullanılmıştır. Öncesinde uygun gecikme uzunluğu belirlenmiştir. Gecikme uzunluğunun belirlenmesinde Akaike Bilgi kriteri göz önünde bulundurulmuştur. Bound test sonuçlarında elde edilen F test istatistik değerleri Pesaran vd. (2001)'de belirtilen alt ve üst kritik değerleri ile karşılşatırılır. F test değeri alt sınırdan küçükse $\mathrm{H}_{0}$ hipotezi olan eşbütünleşme yoktur kabul edilmektedir. Bununla birlikte elde edilen değerler üst sınırdan yüksek ise $\mathrm{H}_{0}$ hipotezi reddedilmektedir. Tablo 3'te görüldüğü üzere F-test değeri KVYKO değişkeni için 8.45, UVYKO değişkeni için 10.53 ve OZKO için 11.14 bulunmuştur. F test istatistik değerlerinin tümü \%1 anlamlllık düzeyinde üst sınır değerinin üzerindedir. Bu nedenle $\mathrm{H}_{0}$ hipotezi reddedilmiş; uluslararasılaşma düzeyi ile kısa vadeli yabancı oranı, uzun vadeli yabancı kaynak oranı ve özkaynak oranı arasında eşbütünleşme olduğu tespit edilmiştir. 
İ. E. Kandil Göker 11/4 (2019) 3448-3457

Tablo 3. Bound Test Sonuçları

\begin{tabular}{|lllllll|}
\hline Model & $\begin{array}{l}\text { Maksimum } \\
\text { gecikme }\end{array}$ & F-Test & Olasılık & $\begin{array}{l}\text { Alt Sınır- } \\
\text { Üst Sınır }\end{array}$ & $\begin{array}{l}\text { Alt Sinır- } \\
\text { Üst Sinır }\end{array}$ & $\begin{array}{l}\text { Alt Sınır- } \\
\text { Üst Sınır }\end{array}$ \\
\hline & & & & $\mathbf{( \% 1 )}$ & $\mathbf{( \% 5 )}$ & $\mathbf{( \% 1 0 )}$ \\
\hline YDS(KVYKO) & 2 & 8.45 & 0.0002 & $5.19-6.84$ & $3.62-4.91$ & $2.91-4.10$ \\
YDS (UVYKO) & 2 & 10.53 & 0.0000 & $5.19-6.84$ & $3.62-4.91$ & $2.91-4.10$ \\
YDS (OZKO) & 2 & 11.14 & 0.0000 & $5.19-6.84$ & $3.62-4.91$ & $2.91-4.10$ \\
\hline
\end{tabular}

Söz konusu modellerin ardışık bağıntı içerip içermediği Breusch-Godfrey LM test ile test edilmiştir. Söz konusu testin $\mathrm{H}_{0}$ hipotezi serinin ardışık bağıntı içermediğini belirtmektedir. Bu durumda üç modelin olasılık değerlerinin de $\% 5$ anlamlılık düzeyinde anlamsız çıkması nedeniyle $\mathrm{H}_{0}$ hipotezi reddedilerek modellerde ardışık bağıntı (otokorelasyon) söz konusu olmadığına kanaat getirilmiştir.

Tablo 4. Breusch-Godfrey LM test Sonuçları

\begin{tabular}{|ll|}
\hline & Olasılık değeri (p) \\
\hline YDS (KVYKO) & 0.8795 \\
YDS (UVYKO) & 0.0693 \\
YDS (OZKO) & 0.2597 \\
\hline
\end{tabular}

Modellerin yapısal kırılma içerip içermediği ise CUSUM test ile araştırılmıştır. Grafik 1, Grafik 2 ve Grafik 3'te görüleceği üzere her üç modelde de $\% 5$ anlamlılık düzeyinde serilerin kritik alan içerisinde yer aldığı tespit edilmiştir. Ardışık bağıntı ve yapısal kırılma test sonuçları modellerinin güvenilirliğini göstermektedir.

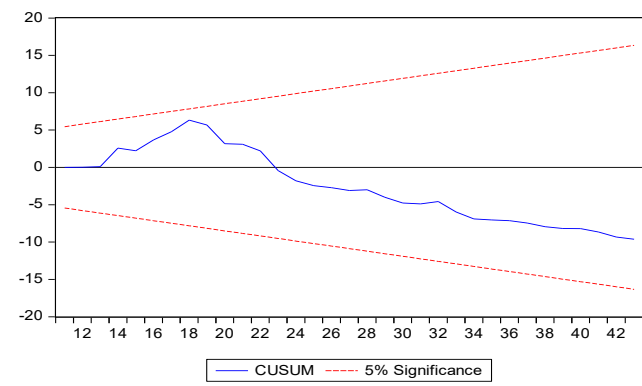

Grafik 1. Model 1 CUSUM Test Sonucu

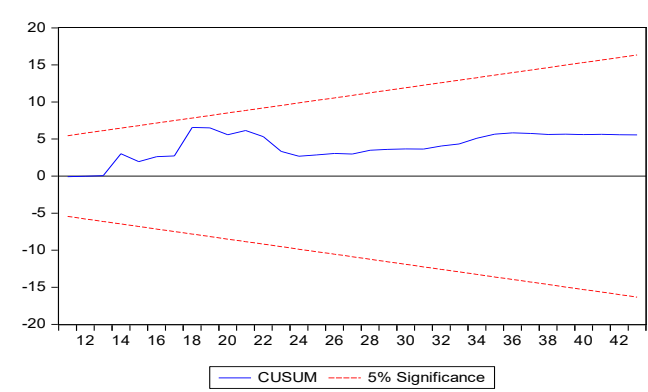

Grafik 3. Model 3 CUSUM Test Sonucu

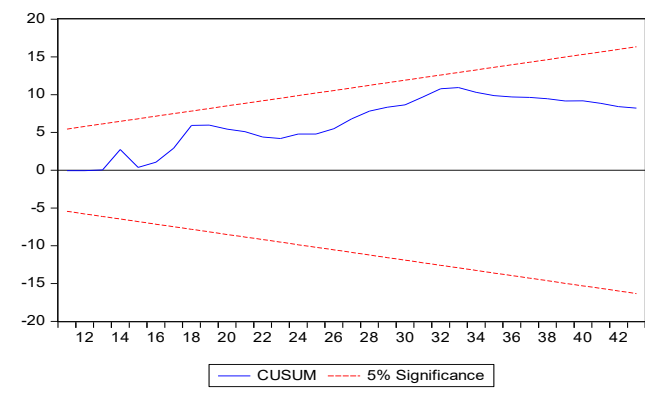

Grafik 2. Model 2 CUSUM Test Sonucu 


\subsubsection{ARDL Modeli Test Sonuçları}

Uluslararasılaşma düzeyi ile ele alınan değişkenler arasındaki uzun dönemli ilişkinin tespiti için (1), (2) ve (3) numaralı modeller kullanılmıştır. Gecikme uzunluğu Akaike Bilgi Kriterine göre belirlenmiştir. Tablo 5 'te gösterilmiş olan sonuçlara göre uluslararasılaşma düzeyi ile ele alınan kaynak unsurları arasında uzun dönemli ve istatistiksel olarak anlamlı bir ilişki olduğu görülmektedir. Söz konusu ilişkinin yönü kısa vadeli yabancı kaynak oranı ile uzun vadeli yabancı oranı için negatif, özkaynak oranı için pozitiftir.

Tablo 5. ARDL Model (1), (2) ve (3) için elde edilen Uzun Dönem Katsayıları

\begin{tabular}{|lccc|}
\hline Model & Katsay1 & T-İstatistik & Olasılık \\
\hline YDS (KVYKO) & -2.944482 & $-1.679249^{* *}$ & 0.100 \\
YDS (UVYKO) & -1.537322 & $-2.812101^{* *}$ & 0.008 \\
YDS (OZKO) & 0.913198 & $1.965367^{* *}$ & 0.050 \\
\hline
\end{tabular}

***, ,**, ${ }^{*}$ sirasıly $\% 1, \% 5$ ve $\% 10$ anlamlılık düzeyini ifade etmektedir.

Uluslararasılaşma düzeyi ile ele alınan değişkenler arasındaki kısa dönemli ilişkinin tespiti için (4), (5) ve (6) numaralı modeller kullanılmıştır. Gecikme uzunluğu yine Akaike Bilgi Kriterine göre belirlenmiştir. Tablo 6'te gösterilmiş Hata Düzeltme Modeli Kısa Dönem İlişki sonuçlara göre KVYKO, UVYKO ve OZKO değişkenlerinin tümünün olasılık değerleri $0.05^{\prime}$ ten büyük olduğu için anlamlı sonuçlar elde edilememiştir. Bu nedenle uluslararasılaşma düzeyi ile ele alınan kaynak unsurları arasında kısa vade için istatistiksel açıdan anlamlı ilişki bulunamamıştır.

Tablo 6. ARDL Model (4), (5) ve (6) için Hata Düzeltme Modeli Kısa Dönem Katsayıları

\begin{tabular}{|l|l|l|l|l|}
\hline & Değişkenler & Katsayı & T-İst. & Olasıllk \\
\hline \multirow{4}{*}{ YDS (KVYKO) } & KVYKO (-1) & 1.804463 & 1.192307 & 0.2414 \\
\cline { 2 - 5 } & KVYKO (-2) & 2.442056 & 1.629678 & 0.1124 \\
\cline { 2 - 5 } & ECT (-1) & -1.048406 & -3.711158 & 0.0007 \\
\hline \multirow{4}{*}{ YDS (UVYKO) } & UVYKO (-1) & 0.379138 & 0.213029 & 0.8326 \\
\cline { 2 - 5 } & UVYKO (-2) & -1.060552 & -0.614748 & 0.5428 \\
\cline { 2 - 5 } & ECT (-1) & -1.556103 & -4.639299 & 0.0001 \\
\hline \multirow{3}{*}{ YDS (OZKO) } & OZKO (-1) & -1.182609 & -0.788466 & 0.4359 \\
\cline { 2 - 5 } & OZKO (-2) & -1.280748 & -0.898213 & 0.3754 \\
\cline { 2 - 5 } & ECT (-1) & -1.451937 & -4.511662 & 0.0001 \\
\hline
\end{tabular}

Yapılan analizler neticesinde çalışmanın temel araştırma sorusunu teşkil eden farklı kaynak unsurlarının uluslararasılaşma üzerindeki etkisi için kısa dönemde anlamlı bulgular elde edilememiş ancak uzun dönem için toplam kaynak yapısı içinde borçlanma düzeyindeki artışın uluslararasılaşmayı negatif yönde etkilerken; özkaynak düzeyindeki artışın pozitif yönde etkilediği tespit edilmiştir.

\section{SONUÇ}

$\mathrm{Bu}$ çalışma işletmelerin uluslararasılaşmasında farklı kaynak unsurlarının etkisini ortaya koymayı amaçlamaktadır. Firmalar için sermayenin oluşturulmasında iki temel kaynak unsuru borç ve özsermayedir. Borç ise vade bakımından kısa vadeli ve uzun vadeli borç olarak sınıflandırılmaktadır. $\mathrm{Bu}$ anlamda kurulan üç farklı model ile kısa vadeli borçlanma oranı, uzun vadeli borçlanma oranı ve özkaynak oranlarının kısa ve uzun dönemde işletmelerin uluslararasılaşmaları üzerindeki etkileri ARDL ve Hata Düzeltme Modeli ile test edilmiştir. Elde edilen bulgulara göre işletmelerin uluslararasılaşmasında farklı kaynak unsurlarının kısa dönemli etkisine yönelik anlamlı sonuçlar tespit edilememiştir. Uzun dönem sonuçlarında ise işletmelerin kısa vadeli borçlanma oranı ve uzun dönemli 


\section{İ. E. Kandil Göker 11/4 (2019) 3448-3457}

borçlanma oranı ile uluslararasılaşma düzeyleri arasında negatif yönlü bir ilişki; özkaynak oranı ile pozitif yönlü bir ilişki tespit edilmiştir. İşletmelerin uzun vadeli borçlanma oranlarındaki 1 birimlik artış uluslararasılaşma düzeylerini 2.94 birim azaltmakta, kısa vadeli borçlanma oranlarındaki 1 birimlik artış uluslararasılaşma düzeylerini 1.53 birim azaltmakta ve son olarak özkaynak/toplam aktif oranlarındaki 1 birimlik artış uluslararasılaşma düzeylerini 0.91 birim artırmaktadır. Bu çalışmada elde edilen bulguların borçlanma düzeyindeki artışın uluslararasılaşma düzeyi ile negatif yönlü bir ilişki içerisinde olduğunu tespit eden Burgman (1996), Chen vd. (1997), Chkir \& Cosset (2001), Doukas \& Pantzalis (2003)'ın bulguları ile tutarlı olduğu görülmüştür. Dokuma Giyim Eşyası ve Deri Sektörü şirketleri için gerek kısa vade gerek uzun vadeli borçlanma oranında yaşanan artış sözü edilen şirketlere finansal yükümlülükler yüklemekte ve bu durumda yöneticiler için beklenen nakit akışlarını ve uluslararasılaşma ihtimallerini azaltıı bir etki yaratmaktadır. Buna karşılık özsermayenin toplam kaynak içindeki payının artması uluslararasılaşmayı pozitif yönde etkilemektedir. Bu nedenle ele alınan sektörün uluslararasılaşma planlarını özsermaye finansmanına dayalı olarak planlamaları gerekmektedir.

Ele alınan çalışma birtakım sınırlılıklar içermektedir. İlk olarak kurulan modellerde uluslararasılaşmayı etkileyebilecek başka faktörler dikkate alınmamıştır, bu anlamda bulguların bu durum dikkate alınarak değerlendirmesi gerekmektedir. Ele alınan örneklem sadece borsaya kote olmuş Dokuma Giyim Eşyası ve Deri Sektörü şirketlerinden oluşmaktadır. Bu nedenle elde edilen bulguların genelleştirme yapılarak yorumlanması mümkün değildir. Son olarak uluslararasılaşma düzeyi işletmelerin hem yurtdışına yapmış oldukları satış hem de yurtdışındaki varlıklarının büyüklüğü ile ölçülmekte iken bu çalışmada işletmelerin yurtdışındaki varlıklarının toplam değerine ilişkin bir veri olmamasından ötürü uluslararasılaşma sadece yurtdışına yapılan satışlar göz önünde bulundurularak ölçülmüştür.

İşletmelerin uluslararasılaşmasını konu alan pek çok çalışma, uluslararası ticaretin yönetim, pazarlama, hukuki boyutlarını ele almıştır. Özellikle uluslararasılaşmanın finansmanı hususu yeterince incelenmemiştir. Devam eden çalışmalar ile uluslararasılaşmanın sermaye maliyeti, çalışma sermayesi yönetimi gibi finansal yönetimin temel hususları üzerindeki etkisi ele alınarak literatüre katkı sağlanacağı düşünülmektedir.

\section{Kaynakça}

Bellone F., Musso P., Nesta L., Schiavo S. (2010). Financial Constraints and Firm Export Bahviour. The World Economy, doi: 10.1111/j.1467-9701.2010.01259.x

Burgman, T.A. (1996). An Empirical Examination of Multinational Corporate Capital Structure, Journal of International Business Studies, 27, 553-570.

Chen C. J.P., Cheng S. C.A., He J., Kim J. (1997). An Investigation of The Relationship Between International Activities and Capital Structure, Journal of International Business Studies, April, 563576.

Chiang Y-C. \& Chen S.-W. (2008). The Relationship Between Internationalization and Capital Structures Of Taiwan Firms, The International Journal of Business and FinanceResearch, 2(1), 1-12.

Chkir I.E., Cosset, J-C. (2001). Diversification Strategy And Capital Structure of Multinational Corporations, Journal of Multinational Financial Management, (11), 17-37.

Doukas, J.A. and Pantzalis, C. (2003), Geographic Diversification And Agency Costs Of Debt of Multinational Firms, Journal of Corporate Finance, 9(1), 59-92.

Jensen, Michael C. (1986). Agency Costs of Free Cash Flow, Corporate Finance, And Takeovers. American Economic Review, 76: 323-29.

Greenaway D. Guariglia A., Kneller R. (2007). Financial Factors and Exporting Decisions, Journal of International Economics, 73(2), 377-395. 
Lee K. Khaw H. (2019). Debt Financing Puzzle And Internationalization, Journal of Asia Business Studies, $13(1), 29-52$.

Mansi, S.A., Reeb, D.M. (2002). Corporate Diversification: What Gets Discounted? Journal of Finance, 57, 2167- 2183 .

Minetti R., Zhu S.C. (2011). Credit Constraints and Firm Export: Microeconomic Evidence from Italy. Journal of International Economics, (83), 109-125.

Pacheco, L. (2017). Financial Structure Effects on Export Intensity And Diversification: The Case of Portuguese Industrial Firms, International Journal of Globalisation and Small Business, Vol.9, No. 4, pp.252-276.

Pesaran M. H.,Shin Y., and Smith R.J.(2001). Bounds Testing Approaches To The Analysis Of Level Relationships, Journal of Applied Econometrics,16(3), 289-326.

Reeb, D.M., Mansi, S.A., Allee, J.M. (2001). Firm Internationalization and The Cost of Debt Financing: Evidence from Non-Provisional Publicly Traded Debt. Journal of Financial and Quantitative Analysis, 36, 395-414.

Shapiro, A. C. (1978). Financial Structure and Cost Of Capital in The Multinational Corporation, Journal of Financial and Quantitative Analysis, 13: 211-26.

Shapiro A. C. (1992). Multinational Financial Management, Boston, Allyn \&Bacon.

Singh M., Nejadmalayeri A. (2004). Internationalization, Capital Structure, And Cost Of Capital: Evidence From French Corporations, Journal of Multinational Financial Management, 14, 153-169. 